\section{Original Research}

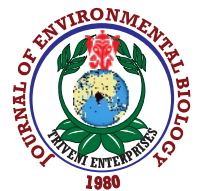

DOI : http://doi.org/10.22438/jeb/42/4(SI)/MRN-1554a

Journal website : www.jeb.co.in $\star$ E-mail : editor@jeb.co.in

Journal of Environmental Biology

\title{
Studies on population dynamics of major pests of Ailanthus excelsa Roxb
}

\author{
V. Manimaran ${ }^{1 *}$, M.Suganthy ${ }^{2}$, A. Balasubramanian ${ }^{3}$ and P.Pretheepkumar ${ }^{4}$ \\ 'Department of Silviculture and NRM, Forest College and Research Institute, Mettupalayam-641 301, India \\ ${ }^{2}$ Department of Silviculture and NRM, Forest College and Research Institute, Mettupalayam-641 301, India \\ ${ }^{3}$ Department of Silviculture and NRM, Forest College and Research Institute, Mettupalayam-641 301, India \\ ${ }^{4}$ National Pulses Research Centre, Vamban-622 303, India \\ *Corresponding Author Email : manimaranfcri111@gmail.com
}

Abstract

Aim: To study the peak period of incidence of major pest of Ailanthus excelsa.

Methodology: Seasonal abundance of major insect pests of $A$. excelsa viz., ailanthus defoliator and ailanthus webworm were studied in 5-year-old plantation at Forest College and Research Institute, Mettupalayam from April, 2018 to March, 2019. Weekly observations were made on the abundance of major insect and pest population which were correlated with weekly weather parameters.

Results: Monitoring the population dynamics of insect pests revealed that the major key pests were ailanthus defoliator and webworm. The highest number of ailanthus defoliator (38.00 larvae per tree) and webworm (33.90 larvae per tree) were recorded during $44^{\text {th }}$ standard week in 5-year-old plantation. Correlation analysis revealed that maximum temperature $\left(T_{\max }\right)$ was negatively correlated with ailanthus defoliator with the $r$ value of -0.299 . Regarding webworm, wind velocity and evaporation rate were negatively correlated with the r value of -0.412 and -0.361 and was found to be statistically significant at $1 \%$ level.

Interpretation: Seasonal abundance of this information helps us to take decision for the management of $A$. excelsa pests.

Key words: Ailanthus excelsa, Defoliator, Population dynamics, webworm

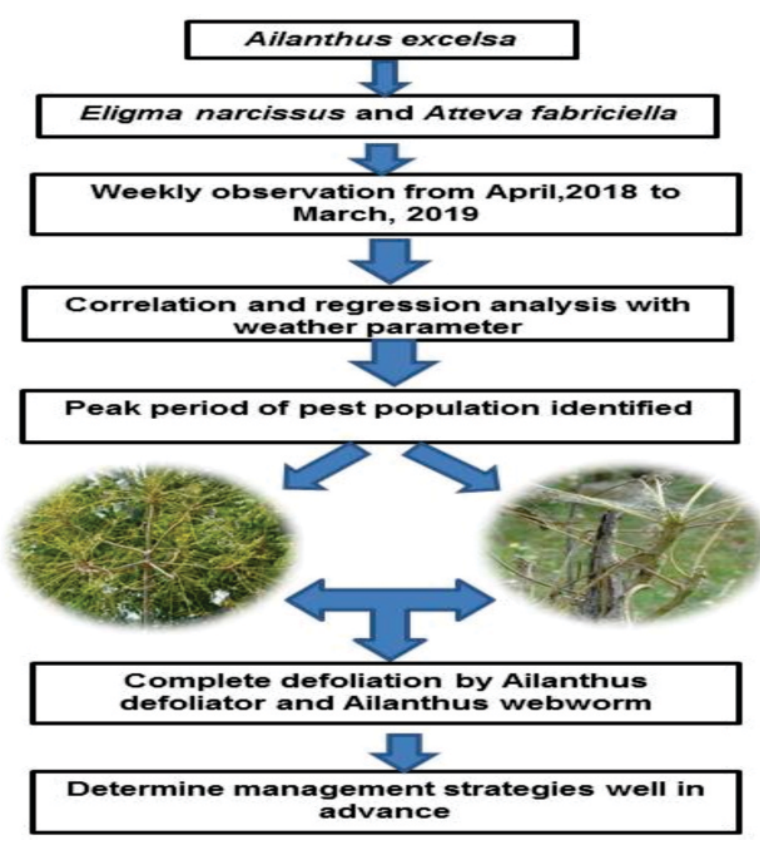

How to cite : Manimaran V., M.Suganthy, A. Balasubramanian and P.Pretheepkumar, Studies on population dynamics of major pests of Ailanthus excelsa Roxb. J. Environ. Biol., 42, 1168-1173 (2021). 


\section{Introduction}

Ailanthus excelsa is a multipurpose, deciduous, fast growing tree species belonging to family Simaroubaceae. It grows well in arid and semi-arid regions, and is suitable for planting in dry areas experiencing annual rainfall of $400 \mathrm{~mm}$. In India, the tree is indigenous to southern and central India and also distributed in Western Peninsula, Rajasthan, Bihar, Orissa, Bundelkhand in Madhya Pradesh, Broach and Panchamal districts of Gujarat, in dry deciduous forests of Maharashtra and scarce in Deccan and Karnataka. It avoids moist areas having high rainfall. It grows in broad range of soil types including sandy soils, adapts to drought stress and can tolerate dry season of 4 to 6 months (Rajasugunasekar, 2014). The demand for $A$. excelsa is increasing due to its multipurpose uses viz., leaves as fodder and stem in the production of match wood, box plank, packing cases, sword sheath, paper, toys, plywood veneers (Sharma et al., 2016), pencil (Lavhale and Mishra, 2007) and fuel wood (Jat et al., 2011). Among the various pests, Eligma narcissus and Atteva fabriciella are the major pests of Ailanthus excelsa. Eligma narcissus causes complete defoliation of seedlings in the nursery and up to $95 \%$ defoliation in the young plantations up to 5 -yearsold, resulting in loss of growth increment (Varma, 1996). Defoliation by Atteva fabriciella leads to reduction in growth increment due to defoliation of tender leaves, forking of tree due to terminal bud damage and loss of seed production due to damage of inflorescence and fruits (Varma, 1996; Nair, 2007).

Wolda, (1988); Pinhiero et al. (2002) reported that the common phenomenon for the abundance of tropical insect is seasonal variation. Change in insect abundance occurs over time for various reasons such as micro and macro climate change and variation in the availability of food resources. Insect can operate faster and more efficiently at higher temperature and can also feed, develop, reproduce and disperse once the climate is warm, although they live for a short period (Drake, 1994). Information on weather parameters of standard weeks is important compared to the annual mean to analyze the population dynamics of pests and natural enemies in relation to changing environmental conditions. Understanding this impact of native weather variables on insect population dynamic is vital for managing pests of tropical crops (Lomelí-Flores et al., 2010)

Therefore, this study was undertaken to determine the effect of climatic parameters on the seasonal abundance of insect pests of $A$. excelsa.

\section{Materials and Methods}

Seasonal abundance of major insect pests of $A$. excelsa viz., Ailanthus defoliator and Ailanthus webworm were studied in 5-year-old plantation at Forest College and Research Institute, Mettupalayam from April, 2018 to March, 2019. Weekly observation were made on the abundance of major insect pests on 10 randomly selected trees on three leaves in the lower whorls for ailanthus defoliator and three leaves on the crown for ailanthus webworm. Weekly counts of insect pest population was correlated with weekly weather parameters viz., maximum temperature $\left(T_{\text {max }}\right)$, minimum temperature $\left(T_{\min }\right)$, relative humidity $(\mathrm{RH})$, rainfall, sunshine, wind speed and evaporation rate obtained from Agro-meteorological Observatory at Forest College and Research Institute, Mettupalayam.

Correlation and multiple linear regression analyses were conducted to assess the relationship between seasonal abundance of insect pests in the field and weather parameters viz., maximum temperature $\left(T_{\max }\right)$, minimum temperature $\left(T_{\min }\right)$, relative humidity $(\mathrm{RH})$, rainfall, sunshine, wind speed and evaporation rate were carried out using SPSS statistics ver.17.0. (Gomez and Gomez, 1984).

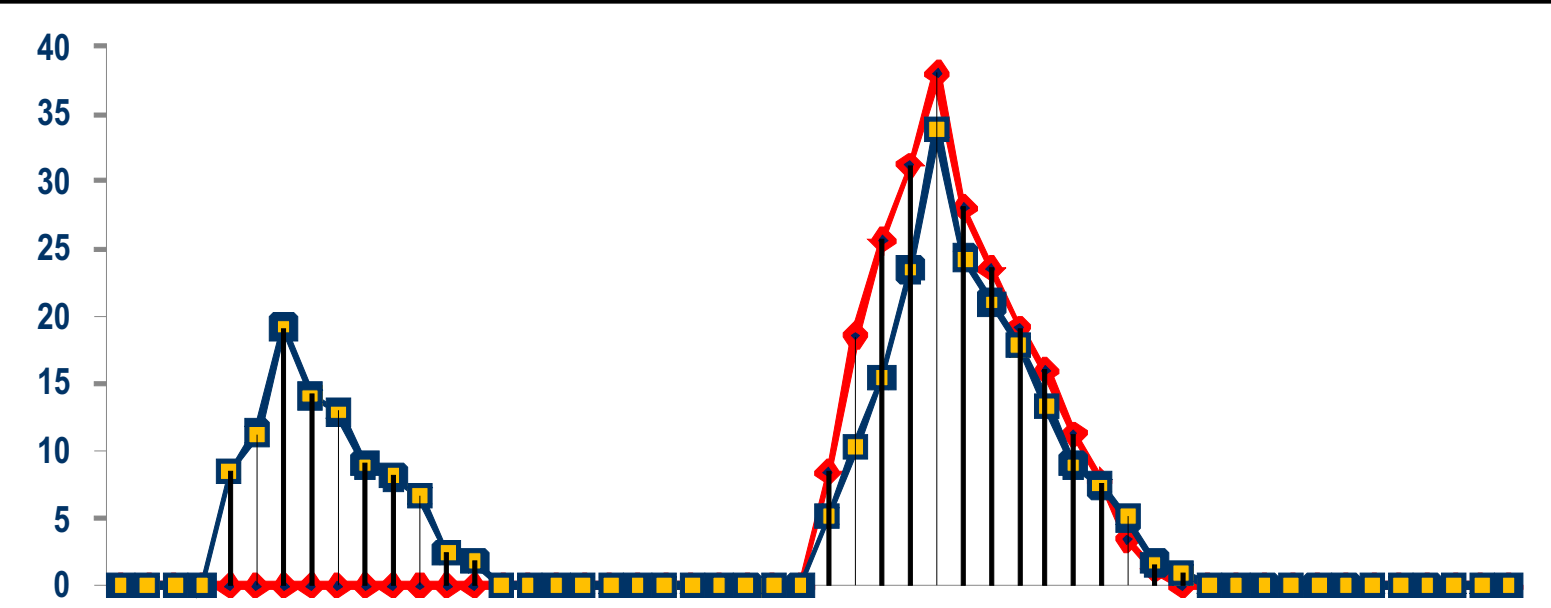

$\begin{array}{llllllllllllllllllllllllll}14 & 16 & 18 & 20 & 22 & 24 & 26 & 28 & 30 & 32 & 34 & 36 & 38 & 40 & 42 & 44 & 46 & 48 & 50 & 52 & 2 & 4 & 6 & 8 & 10 & 12\end{array}$ Standard week

$\longrightarrow$ Ailanthus defoliator $\quad-$ Ailanthus webworm

Fig.1.: Seasonal abundance of defoliators infesting 5-year-old plantation of Ailanthus excelsa during 2018-2019 
Table 1: Monitoring insect pests in 5-year-old plantation of $A$. excelsa during 2018-19*

\begin{tabular}{|c|c|c|c|c|}
\hline Date / Months & $\begin{array}{l}\text { Standard } \\
\text { week }\end{array}$ & $\begin{array}{l}\text { Ailanthus defoliator } \\
\text { (No. per tree) }\end{array}$ & $\begin{array}{l}\text { Ailanthus webworm } \\
\text { (No. per tree) }\end{array}$ & Defoliation (\%) \\
\hline \multicolumn{5}{|l|}{2018} \\
\hline 01 to 07 April & 14 & 0.00 & 0.00 & 0.00 \\
\hline 08 to 14 April & 15 & 0.00 & 0.00 & 0.00 \\
\hline 15 to 21 April & 16 & 0.00 & 0.00 & 0.00 \\
\hline 22 to 28 April & 17 & 0.00 & 0.00 & 0.00 \\
\hline 30 to 06 May & 18 & 0.00 & 8.50 & 1.00 \\
\hline 07 to 13 May & 19 & 0.00 & 11.30 & 5.00 \\
\hline 14 to 20 May & 20 & 0.00 & 19.20 & 8.00 \\
\hline 21 to 27 May & 21 & 0.00 & 14.10 & 12.00 \\
\hline 28 to 03 June & 22 & 0.00 & 12.90 & 15.00 \\
\hline 04 to 10 June & 23 & 0.00 & 9.00 & 10.00 \\
\hline 11 to 17 June & 24 & 0.00 & 8.10 & 8.00 \\
\hline 18 to 24 June & 25 & 0.00 & 6.70 & 5.00 \\
\hline 25 to 01 July & 26 & 0.00 & 2.40 & 2.00 \\
\hline 02 to 08 July & 27 & 0.00 & 1.80 & 0.00 \\
\hline 09 to 15 July & 28 & 0.00 & 0.00 & 0.00 \\
\hline 16 to 22 July & 29 & 0.00 & 0.00 & 0.00 \\
\hline 23 to 29 July & 30 & 0.00 & 0.00 & 0.00 \\
\hline 30 to 05 August & 31 & 0.00 & 0.00 & 0.00 \\
\hline 06 to 12 August & 32 & 0.00 & 0.00 & 0.00 \\
\hline 13 to 19 August & 33 & 0.00 & 0.00 & 0.00 \\
\hline 20 to 26 August & 34 & 0.00 & 0.00 & 0.00 \\
\hline 27 to 02 September & 35 & 0.00 & 0.00 & 0.00 \\
\hline 03 to 09 September & 36 & 0.00 & 0.00 & 0.00 \\
\hline 10 to 16 September & 37 & 0.00 & 0.00 & 0.00 \\
\hline 17 to 23 September & 38 & 0.00 & 0.00 & 0.00 \\
\hline 24 to 30 September & 39 & 0.00 & 0.00 & 0.00 \\
\hline 01 to 07 October & 40 & 8.40 & 5.20 & 2.00 \\
\hline 08 to 14 October & 41 & 18.60 & 10.30 & 25.00 \\
\hline 15 to 21 October & 42 & 25.60 & 15.40 & 35.00 \\
\hline 22 to 28 October & 43 & 31.20 & 23.50 & 55.00 \\
\hline 29 to 04 November & 44 & 38.00 & 33.90 & 75.00 \\
\hline 05 to 11 November & 45 & 28.00 & 24.30 & 80.00 \\
\hline 12 to 18 November & 46 & 23.50 & 21.00 & 82.00 \\
\hline 19 to 25 November & 47 & 19.10 & 17.80 & 85.00 \\
\hline 26 to 02 December & 48 & 16.00 & 13.40 & 88.00 \\
\hline 03 to 09 December & 49 & 11.30 & 9.00 & 70.00 \\
\hline 10 to 16 December & 50 & 7.70 & 7.50 & 55.00 \\
\hline 17 to 23 December & 51 & 3.50 & 5.10 & 30.00 \\
\hline 24 to 31 December & 52 & 1.20 & 1.70 & 10.00 \\
\hline \multicolumn{5}{|l|}{2019} \\
\hline 01 to 07 January & 01 & 0.00 & 0.90 & 3.00 \\
\hline 08 to 14 January & 02 & 0.00 & 0.00 & 0.00 \\
\hline 15 to 21 January & 03 & 0.00 & 0.00 & 0.00 \\
\hline 22 to 28 January & 04 & 0.00 & 0.00 & 0.00 \\
\hline 29 to 04 February & 05 & 0.00 & 0.00 & 0.00 \\
\hline 05 to 11 February & 06 & 0.00 & 0.00 & 0.00 \\
\hline 12 to 18 February & 07 & 0.00 & 0.00 & 0.00 \\
\hline 19 to 25 February & 08 & 0.00 & 0.00 & 0.00 \\
\hline 26 to 04 March & 09 & 0.00 & 0.00 & 0.00 \\
\hline 05 to 11 March & 10 & 0.00 & 0.00 & 0.00 \\
\hline 12 to 18 March & 11 & 0.00 & 0.00 & 0.00 \\
\hline 19 to 25 March & 12 & 0.00 & 0.00 & 0.00 \\
\hline 26 to 01 April & 13 & 0.00 & 0.00 & 0.00 \\
\hline Mean & - & 4.46 & 5.44 & 14.63 \\
\hline
\end{tabular}

\footnotetext{
* - Data presented without statistical analysis
} 


\section{Results and Discussion}

Monitoring of seasonal abundance of insect pests in five years old plantation by direct counting revealed that the highest number of ailanthus defoliator was recorded during $44^{\text {th }}$ standard week of 2018 (38.00 larvae per tree) and the minimum number of larvae was recorded during $52^{\text {nd }}$ standard week (1.20). Ailanthus defoliator was not noticed till $39^{\text {th }}$ standard week of 2018 in 5year-old plantation. The incidence started during $40^{\text {th }}$ standard week (8.40 larvae per tree), increased gradually, attained peak during $44^{\text {th }}$ standard week and then declined thereafter. The larval population disappeared from first to $13^{\text {th }}$ standard week of 2019 (Figure 1) and coincide with the findings of findings of Varma (1986) who has reported the peak incidence of both $E$. narcissus and $A$. fabriciella during September to January in 2-year-old plantation of $A$. triphysa in Kerala.

Regarding Ailanthus webworm, the highest number of webworm was recorded during $44^{\text {th }}$ standard week (33.90 larvae per tree) and the minimum number larvae was recorded during $1^{\text {st }}$ standard week of 2019 (0.90 larvae per tree). During the observation period of one year, the population of webworm was noticed twice. The first incidence started during $18^{\text {th }}$ standard week (8.5 per tree), increased gradually, attained first peak during $20^{\text {th }}$ standard week (19.20), declined gradually and disappeared from $28^{\text {th }}$ to $39^{\text {th }}$ standard week. Second incidence of webworm started during $40^{\text {th }}$ standard week and extended till first standard week of 2019, with the second peak population (33.90 larvae per tree) during $44^{\text {th }}$ standard week (Table 1). The present study are in conformity with the earlier study, where, $A$. triphysa defoliators was found to be abundant from November to February, coinciding with the general flushing period of tree and smaller population was present throughout the year, thriving on small quantities of new leaves (Varma, 1991) and the peak population of $A$. fabriciella during the onset of monsoon in June-July, with the lowest population in summer months (Mathur et al.,1970).

The results of correlation analysis between weather parameters and abundance of ailanthus defoliator revealed that the maximum temperature $\left(T_{\text {max }}\right)$ was negatively correlated with the population of Ailanthus defoliator with the $r$ value of -0.299 and was found to be statistically significant at $5 \%$ level. The minimum temperature, relative humidity and sunshine were also negatively correlated with $r$ value of $-0.259,-0.143$ and -0.364 , respectively. Rainfall was positively correlated with $r$ value of 0.206 , while, wind velocity and evaporation rate were negatively correlated with $r$ value of -0.495 and -0.499 , respectively and were found to be statistically significant at $1 \%$ level (Table 2 ). The

Table 2. Influence of weather parameters on seasonal abundance of Ailanthus defoliator and A. webworm in 5-year-old plantation during 2018-19

\begin{tabular}{|c|c|c|}
\hline \multirow[t]{2}{*}{ Variables } & \multicolumn{2}{|c|}{ Correlation coefficient } \\
\hline & Ailanthus defoliator & Ailanthus webworm \\
\hline Maximum temperature $\left(\mathrm{T}_{\max }\right)\left({ }^{\circ} \mathrm{C}\right)$ & $-0.299^{\star \star}$ & -0.133 \\
\hline Minimum temperature $\left(\mathrm{T}_{\min }\right)\left({ }^{\circ} \mathrm{C}\right)$ & -0.259 & -0.134 \\
\hline Relative humidity (\%) & -0.143 & -0.222 \\
\hline Rainfall (mm) & 0.206 & 0.163 \\
\hline Sunshine (h/day) & -0.364 & -0.091 \\
\hline Wind velocity $(\mathrm{km} / \mathrm{h})$ & $-0.495^{\star}$ & $-0.412^{*}$ \\
\hline Evaporation rate $(\mathrm{mm})$ & $-0.499^{*}$ & $-0.361^{*}$ \\
\hline
\end{tabular}

${ }^{* *}$ Correlation coefficient is significant at $5 \%$ level

${ }^{*}$ Correlation coefficient is significant at $1 \%$ level

Table 3. Multiple linear regression analysis for the prediction of seasonal abundance of Ailanthus defoliator and A. webworm in 5-year-old plantation during 2018-19

\begin{tabular}{|c|c|c|}
\hline \multirow[t]{2}{*}{ Variables } & \multicolumn{2}{|c|}{ Regression coefficient } \\
\hline & Ailanthus defoliator $\left(Y_{1}\right)$ & Ailanthus webworm $\left(\mathrm{Y}_{2}\right)$ \\
\hline Intercept (a) & 20.526 & 30.103 \\
\hline Maximum temperature $\left(\mathrm{T}_{\max }\right)\left({ }^{\circ} \mathrm{C}\right)\left(\mathrm{X}_{1}\right)$ & $1.344^{*}$ & 0.555 \\
\hline Minimum temperature $\left(\mathrm{T}_{\min }\right)\left({ }^{\circ} \mathrm{C}\right)\left(\mathrm{X}_{2}\right)$ & 0.436 & $0.908^{* *}$ \\
\hline Relative humidity $(\mathrm{RH})(\%)\left(\mathrm{X}_{3}\right)$ & -0.394 & $-0.429^{*}$ \\
\hline Rainfall $(\mathrm{mm})\left(\mathrm{X}_{4}\right)$ & -0.013 & -0.043 \\
\hline Sunshine (h/day) $\left(X_{5}\right)$ & 0.035 & $4.077^{*}$ \\
\hline Wind velocity $(\mathrm{km} / \mathrm{h})\left(\mathrm{X}_{6}\right)$ & -4.178 & $-3.960^{\star *}$ \\
\hline Evaporation rate $(\mathrm{mm})\left(\mathrm{X}_{7}\right)$ & $-7.074^{\star *}$ & $-10.943^{*}$ \\
\hline $\mathrm{R}^{2}$ & 0.374 & 0.463 \\
\hline
\end{tabular}

Regression equations

1) $\left.Y_{1}=20.085+1.334^{*} X_{1}+0.436 X_{2}-0.394 X_{3}-0.013 X_{4}+0.035 X_{5}-4.178 X_{6}-7.074^{* *} X_{7} ; 2\right) Y_{2}=30.103+0.555 X_{1}+0.908^{* *} X_{2}-0.429^{*} X_{3}-0.043 X_{4}+$ $4.077^{*} X_{5}-3.960^{\star *} X_{6}-10.943^{*} X_{7}$; ${ }^{* *}$ Regression coefficient is significant at $5 \%$ level

${ }^{*}$ Regression coefficient is significant at $1 \%$ level 
present findings are in conformity with the findings of Kumar et al. (2007) who have reported that tobacco caterpillar, Spodoptera litura had non-significant correlation with maximum temperature, minimum temperature, relative humidity and rainfall.

In case of Ailanthus webworm incidence, rainfall was positively correlated with webworm population with the $r$ value of 0.163 . Whereas, wind velocity and evaporation rate were negatively correlated with the $r$ value of -0.412 and -0.361 and were found to be statistically significant at $1 \%$ level. The maximum temperature $\left(T_{\text {max }}\right)$, minimum temperature $\left(T_{\text {min }}\right)$, relative humidity and sunshine were negatively correlated with the population of webworm with the r value of $-0.133,-0.134$, 0.222 and -0.091 (Table 2). The present study is in conformity with the findings of Varma (1986) who reported that occurrence of defoliators was low during rainy season, but there was no definite correlation between pest incidence and rainfall because of population of $A$. fabriciella was observed throughout the year(Varma, 1991) and the population of leaf webber were negatively correlated with minimum and maximum temperature and positively correlated with relative humidity and rainfall in Vigna mungo (Umesh et al., 2010).

Multiple linear regression analysis between weather parameters and abundance of Ailanthus defoliator in 5-year-old plantation revealed that evaporation rate had significant contribution towards Ailanthus defoliator population with the $\mathrm{R}^{2}$ value of 0.374 at $5 \%$ level. When the rate of evaporation increased by $1 \mathrm{~mm}$, the mean number of larval population decreased by 7.074 per tree. The maximum temperature $\left(\mathrm{T}_{\max }\right)$ also had significant contribution towards the defoliator population at $1 \%$ level. When the maximum temperature increased by $1^{\circ} \mathrm{C}$, defoliator population increased by 1.344 larvae per tree (Table 3).

The minimum temperature and wind velocity had significant contribution towards the abundance of Ailanthus webworm at $5 \%$ level with $R^{2}$ value of 0.463 . When minimum temperature increased by $1^{\circ} \mathrm{C}$, the webworm population increased by 0.908 larvae per tree, whereas, increase in wind velocity by $1 \mathrm{~km} \mathrm{~h}^{-1}$ had decreased the webworm population by 3.960 larvae per tree. Relative humidity, sunshine and evaporation rate also contributed significantly towards the webworm population at $1 \%$ level. When the relative humidity increased by $1 \%$, larval population decreased by 0.429 per tree whereas increase in sunshine by $1 \mathrm{~h} /$ day had significantly increased the population of webworm by 4.077 per tree. When the evaporation rate increased by $1 \mathrm{~mm}$, the webworm population decreased by 10.943 larvae per tree (Table 3 ). The results of present study on defoliators are in conformity with the finding of William and Andrew (1995) who reported that increase in temperature by $2^{\circ} \mathrm{C}$ had reduced the defoliation by spruce budworm and increased defoliation by gypsy moth. William and Andrew (1995) has also stated that increase in temperature by $2^{\circ} \mathrm{C}$ with an increase of $0.5 \mathrm{~mm}$ precipitation per day had increased the defoliation by both budworm and gypsy moth in spruce. Guedes et al. (2000) reported that 6 to 7 years old plantations of Eucalyptus grandis under the temperature of $18^{\circ} \mathrm{C}$ registered maximum incidence of Stenalcidia grosica.
Considering the significance of Ailanthus as a multipurpose agroforestry tree species, this study on seasonal abundance of pests of Ailanthus excelsa will be helpful to determine the peak period of pest incidence in Ailanthus and then correlation between the defoliator population and weather parameters will help to predict the pest outbreak, forewarn the farmers and to determine the management strategies well in advance.

\section{Add-on Information}

Authors' contribution: V. Manimaran: Writing full article and statistical analysis; M. Suganthy: Technical guidance for table preparation; A. Balasubramanian: Correction of the manuscript; P. Pretheep Kumar: Reference part.

Research content: The research content is original and has not been published elsewhere.

\section{Ethical approval: NotApplicable}

Conflict of interest: The authors declare that there is no conflict of interest.

\section{Data from other sources: NotApplicable}

Consent to publish: All authors agree to publish the paper in Journal of Environmental Biology.

\section{References}

Drake, V.A.: The influence of weather and climate on agriculturally important insects: An Australia perspective. Austr. J. Agricul. Res., 45, 487-509 (1994).

Gomez, K.A. and A.A. Gomez: Statistical Procedures for Agricultural Research. John Wiley \& Sons (1984)

Guedes, R.N.C., T.V. Zanuncio, J.C. Zanuncio and A.G.B. Medeiros: Species richness and fluctuation of defoliator Lepidoptera populations in Brazilian plantations of Eucalyptus grandis as affected by plant age and weather factors. Forest Ecol. Manag., 137, 179-184 (2000).

Jat, H.S., R.K.Singh, and J.S. Mann: Ardu (Ailanthus sp) in arid ecosystem: A compatible species for combating with drought and securing livelihood security of resource poor people. Indian J. Trad. Know., 10, 102-113 (2011).

Kumar, R., S. Ali and U. Chandra: Seasonal incidence of insect-pests on Vigna mungo and its correlation with abiotic factors. Annals Plant Protec. Sci., 15., 66-369 (2007).

Lavhale, M.S., and S.H. Mishra: Nutritional and therapeutic potential of Ailanthus excelsa- A review. Pharmacognosy Reviews, 1, 106116 (2007).

Lomelí-Flores, J. R., J. F. Barrera and J. S. Bernal: Impacts of weather, shade cover and elevation on coffee leafminer Leucoptera coffeella (Lepidoptera: Lyonetiidae) population dynamics and natural enemies. Crop Protection, 29, 1039-1048 (2010).

Mathur, R.N., P.N. Chatterjee and S. Sen: Biology, ecology and control of Ailanthus defoliator Atteva fabriciella Swed.(Lepidoptera: Yponomeutidae) in Madhya Pradesh. Indian Forester, 96 538552 (1970).

Nair KS Sadasivan:Tropical Forest Insect Pests: Ecology, Impact, and Management. Cambridge University Press (2007).

Pinheiro, M.H.O., R. Monteiro and O. Cesar: Levantamento fitossociológico da floresta estacional semidecidualdo Jardim 
Botânico Municipal de Bauru, São Paulo. Naturalia, 27, 145164 (2002).

Rajagunasekar D.: Cultivation Techniques for Ailanthus excelsa, Transfer of Tree Cultivation Technologies: Institute of Forest Genetics and Tree breeding (IFGTB), pp. 19-22 (2014).

Sharma, M., N. Sharma., K.K. Srivastava, and A. Parmar: Population dynamics of major insect pests on Ailanthus excelsa Roxb. and their management in arid and semi-arid areas of Rajasthan and Gujarat. Indian Forester, 142, 900-912 (2016).

Umesh, C., S. Kumud., H.M. Singh and K. Rakesh: Seasonal incidence of defoliators in urd bean (Vigna mungo L. Hepper) and their correlation with meteorological parameters. Int. J. Plant Protec., 3,197-199 (2010).

Varma R.V.: Impact of Atteva fabricella (Lepidoptera: Yponomeutidae) on growth of Ailanthus triphysa. Indian Forester, 122, 311-316 (1996).

Varma, R.V.: Spatial and temporal distribution of Ailanthus pests, Eligma narcissus and Atteva fabriciella. Kerala Forest Research Institute, KFRI Research Report, 78, 1-39 (1991).

Varma, R.V.: Seasonal incidence and possible control of important insect pests in plantations of Ailanthus triphysa. Kerala Forest Research Institute, Peechi, Kerala, KFRI Research Report, 39, 1-42(1986)

William, W.D., and M.L. Andrew: Forest defoliators and cfunatic change: Potential changes in spatial distribution of outbreaks of Western spruce budworm (Lepidoptera: Tortricidae) and Gypsy Moth (Lepidoptera: Lymantriidae). Environ. Entomol., 24, 1-9 (1995).

Wolda, H.: Insect seasonality: Why? Annual Rev. Ecol. Syst.,19 1-18 (1988). 